Limnol. Rev. (2014) 14,1: 21-31

DOI 10.2478/limre-2014-0003

\title{
The structure and spatial heterogeneity of zooplankton in small lake river Wel (Poland)
}

\author{
Paweł Napiórkowski ${ }^{1}$, Teresa Napiórkowska ${ }^{2}$ \\ ${ }^{1}$ Department of Hydrobiology, Faculty of Biology and Environmental Protection, Nicolaus Copernicus University in Toruń, Lwowska \\ 1,87-100 Toruń, Poland, e-mail: pnapiork@umk.pl (corresponding author) \\ ${ }^{2}$ Department of Invertebrate Zoology, Faculty of Biology and Environmental Protection, Nicolaus Copernicus University in Toruń, \\ Lwowska 1, 87-100 Toruń, Poland
}

\begin{abstract}
The aim of the study was to determine changes in potamoplankton structure caused by lakes in the fluvial system of the small River Wel. The river flows through 10 lakes. The study was conducted in 2007 and 2008. The selection of sites enabled the assessment of the impact exerted by hydrological conditions of the river on zooplankton, as well as the determination of the effect of lakes situated within the river course on the analysed assemblage of organisms. In total 95 species were determined with an average abundance 1026 ind. $10 \mathrm{dm}^{-3}$. Rotifers dominated qualitatively and quantitatively and among crustaceans - Copepods. Lakes seem to be the main source of zooplankton in the fluvial system of the Wel River. The lakes disturb the river continuum, but their impact on the structure of zooplankton is short-lived. Due to the presence of flow-through lakes along the river, species richness of zooplankton in the Wel River is similar to that in large rivers.
\end{abstract}

Key words: fluvial system, river continuum, potamoplankton, Rotifers, Cladocera, Copepoda

\section{Introduction}

According to the River Continuum Concept (RCC) (Vannotte et al. 1980), physical variables present a continuous gradient in hydrological conditions in an ideal, freely flowing river, which conforms with the biological organisation. The RCC provides also a theory for the dynamics of plankton communities in lotic waters. Regulation of rivers and dam constructions are considered to be the major factors contributing to significant modifications of river ecosystems. Dams disturb the river continuum and change the hydrologic regimes, which is of major significance for structuring the biotic diversity within the river systems (Ward and Stanford 1995; Pourriot et al. 1997; Kentzer et al. 2010).

Also in natural river systems, lakes inserted into the fluvial system provide the examples of the river continuum disturbance which is analogous to man-made barriers on large river systems (HillbrichtIlkowska 1999).
There are two hypotheses explaining the origin and development of the river plankton. The first states that river plankton communities develop within long rivers where organisms have enough time to grow and reproduce as they move downstream (Basu and Pick 1996). The second hypothesis states that lake outlets are a primary source of river plankton (Szlauer 1977; Kobayashi 1997; Czerniawski and Domagała 2012). So the qualitative and quantitative structure of plankton in short rivers is mainly determined by lakes through which a given river flows (Ejsmont-Karabin and Węgleńska 1996; Czerniawski 2008).

According to the RCC potamoplankton should slowly but continuously develop and change downstream in the natural river (Viroux 1997, 1999; Zimmermann-Timm et al. 2007). However lakes inserted into the fluvial system could disturb the river continuum and provide planktonic invertebrates.

The aim of the study was to evaluate the impact of lakes in the fluvial system on potamoplankton structure in a natural river - the River Wel, and study the origin of potamoplankton in the river. 


\section{Study area description}

The Wel River is situated within the Baltic Sea catchment area. It is the biggest, left-bank tributary of the Drwęca River, which in turn is situated within the drainage basin of the Vistula River. The length of the Wel River is $128 \mathrm{~km}$, and has a catchment area of $822.44 \mathrm{~km}^{2}$ (Czarnecka 2005). The Wel River is a lake river that flows through 10 lakes (Fig. 1). Due to the fact that the lakes are storage reservoirs, the Wel River is characterised by a relatively balanced flow throughout the year. The average annual flow fluctuates around ca. $8 \mathrm{~m}^{3} \mathrm{~s}^{-1}$ at the river mouth.

\section{Methods}

The study was conducted for 14 months in 2007/2008. Samplings were carried out every other month in 2007 (from April to October) and on a monthly basis in 2008 (from January to November, except May). In 2007 samples were collected at 6 sites and in 2008 at 7 sites (adittional site was 3a). All sites were numbered starting from the site situated in the upper reaches of the river (Fig. 1)

Site no. 1 - Dąbrówno ( $\left.53^{\circ} 25^{\prime} 24^{\prime \prime} \mathrm{N}, 20^{\circ} 02^{\prime} 18^{\prime \prime} \mathrm{E}\right)$. The site is located in the upper reaches of the river right after the lakes Dąbrowa Wielka and Dąbrowa Mała.

Site no. 2 - Szczupliny ( $\left.53^{\circ} 22^{\prime} 35^{\prime \prime} \mathrm{N}, 20^{\circ} 00^{\prime} 19^{\prime \prime} \mathrm{E}\right)$. The site is situated just before Lake Rumian, at a bridge in the Szczupliny village.

Site no. 3 - Grabacz ( $\left.53^{\circ} 20^{\prime} 09^{\prime \prime} \mathrm{N}, 19^{\circ} 56^{\prime} 51^{\prime \prime} \mathrm{E}\right)$. The site is situated in the middle reaches of the river, where agricultural lands and fish ponds dominate the land uses.

Site no. $3 a$ - Rumian ( $\left.53^{\circ} 22^{\prime} 59^{\prime \prime} \mathrm{N}, 19^{\circ} 59^{\prime} 12^{\prime \prime} \mathrm{E}\right)$. The site is located after the outflow of the river from Lake Rumian.

Site no. 4 - Koszelewki (5319' 13” N, $19^{\circ} 53^{\prime} 21^{\prime \prime}$ E). The site is located ca. $1000 \mathrm{~m}$ after lakes Tarczyńskie and Grądy.

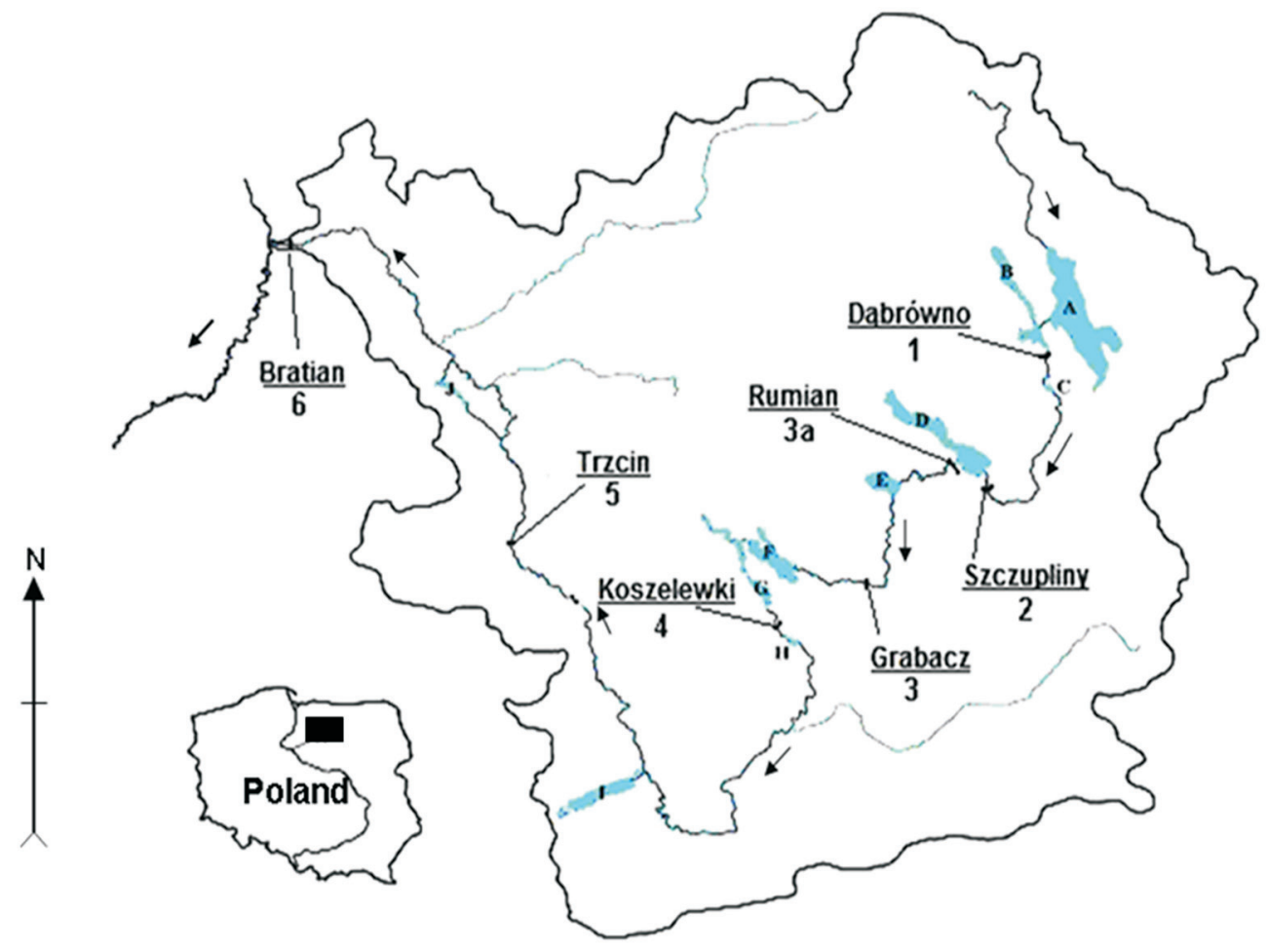

Fig. 1. Distribution of the research sites along the river course (lakes: A - Dąbrowa Wielka, B - Dąbrowa Mała, C - Pancer, D - Rumian, E - Zarybinek, F - Tarczyńskie, G - Grądy, H - Zakrocz, I - Lidzbarskie, J - Fabryczne) 
Site no. 5 - Trzcin ( $\left.53^{\circ} 22^{\prime} 14^{\prime \prime} \mathrm{N}, 1^{\circ} 44^{\prime} 56^{\prime \prime} \mathrm{E}\right)$. At this point the slope of the riverbed exceeds $4 \%$, and the river becomes a mountain stream.

Site no. 6 - Bratian (532 $27^{\prime} 30^{\prime \prime} \mathrm{N}, 1^{\circ} 36^{\prime} 34^{\prime \prime} \mathrm{E}$ ). The site is located ca. $300 \mathrm{~m}$ before the estuary of the Wel River into the Drwęca River.

The location of the sites enabled to assess the impact of the hydrological conditions of the river and lakes situated within the river course on the analysed communities of organisms. The water for analyses was collected from the main stream zone of the river with a 1-litre Patalas plankton trap. For every zooplankton sample ten liters of water was filtered each time through a plankton net of ca. $50 \mu \mathrm{m}$ mesh size. In total 94 both qualitative and quantitative samples were collected. All samples were preserved with Lugol's solution (Nogrady et al. 1993; Harris et al. 2000). Together with the collection of zooplankton samples, physical and chemical parameters of water were studied, such as $\mathrm{pH}$, conductivity (EC), total phosphorus (TP), mineral nitrogen $\left(\mathrm{N}_{\text {min }}\right)$, organic nitrogen $\left(\mathrm{N}_{\text {org }}\right)$, particulate matter $(\mathrm{PM})$, organic matter $(\mathrm{OM})$ and chlorophyll $a$. The physical and chemical methodology was described by Golterman (1971), Greenberg et al. (1992), Mieszczankin (2000), Mieszczankin (2009) and Operacz et al. (2011).

The zooplankton analysis (identification and count) was performed with the use of a light microscope Nikon Alphaphot YS2, as well as a Panasonic camera and software for image analysis - MultiScan. For each sample $\left(10 \mathrm{~cm}^{3}\right)$ five counts were made on a Segdwick-Rafter chamber (Edmondson and Winberg 1971; McCauley 1984). Abundance was expressed as individuals per $10 \mathrm{dm}^{3}$ of water.

The dominance index (D) was applied to determine the structure of species dominance (Kasprzak and Niedbała 1981). The following formula was used:

$\mathrm{D}=100 \mathrm{n} / \mathrm{N}$,

where: $\mathrm{n}$ - number of individuals of a given species, and $\mathrm{N}$ - total number of individuals.
Species were determined as dominants according to the following classification: (i) D5 - eudominants, constitute $>10.0 \%$ total number of individuals, (ii) D4 - dominants, constitute $5.1-10.0 \%$ total number of individuals, (iii) D3 - subdominants, constitute 2.1$5.0 \%$ total number of individuals, (iv) D2 - recedents, constitute $1.1-2.0 \%$ total number of individuals, and (v) D1 - subrecedents, constitute $<1.1 \%$ total number of individuals.

In order to determine the relationship between the abundance of zooplankton and the physico-chemical factors, Pearson's correlation coefficient (r) was applied. The similarity between zooplankton assemblages at sites of the river was determined by cluster analysis using the software STATISTICA.

In order to check the normality of distributions for all variables, the Shapiro-Wolf test was applied. The variables were logarithmically transformed to normalize the data. Statistical significance of the differences between the sites was tested by the analysis of variance ANOVA on $\log (\mathrm{x})$ transformed data of zooplankton abundance and was expressed by the Tukey's HSD (Honestly Significance Differences) post hoc test (Clarke 1993; Thorp and Casper 2003; Hill and Lewicki 2005). All tests were carried out using the software STATISTICA.

\section{Results}

\section{General composition of zooplankton}

In total 95 zooplankton species were recorded: 69 species of Rotifera which constitutes $73 \%$ of all determined species, 18 Cladocera (19\%) and 8 Copepoda (8\%) (Table 1$)$.

The average abundance of the zooplankton in the Wel River during the study period was 1026 ind. $10 \mathrm{dm}^{-3}$ (from 230 to 2300 ind. $10 \mathrm{dm}^{-3}$ ). Rotifera were the dominant group (contributing $57 \%$ to the total zooplankton), while copepoda dominated among crustaceans, contributing $39 \%$ to the total zooplank-

Table 1. The number of zooplankton species and (\%) contribution of individual groups

\begin{tabular}{|c|c|c|c|c|c|c|c|c|c|c|c|c|c|c|}
\hline & \multicolumn{2}{|c|}{ Site 1} & \multicolumn{2}{|c|}{ Site 2} & \multicolumn{2}{|c|}{ Site $3 a$} & \multicolumn{2}{|c|}{ Site 3} & \multicolumn{2}{|c|}{ Site 4} & \multicolumn{2}{|c|}{ Site 5} & \multicolumn{2}{|c|}{ Site 6} \\
\hline & $\mathrm{n}$ & $\%$ & $\mathrm{n}$ & $\%$ & $\mathrm{n}$ & $\%$ & $n$ & $\%$ & $\mathrm{n}$ & $\%$ & $\mathrm{n}$ & $\%$ & $\mathrm{n}$ & $\%$ \\
\hline ROTIFERA & 35 & 76 & 33 & 85 & 29 & 81 & 39 & 87 & 36 & 64 & 28 & 88 & 36 & 88 \\
\hline CLADOCERA & 9 & 19 & 4 & 10 & 4 & 11 & 5 & 11 & 12 & 21 & 3 & 9 & 4 & 10 \\
\hline COPEPODA & 2 & 5 & 2 & 5 & 3 & 8 & 1 & 2 & 8 & 15 & 1 & 3 & 1 & 2 \\
\hline SUM & 46 & 100 & 39 & 100 & 36 & 100 & 45 & 100 & 56 & 100 & 32 & 100 & 41 & 100 \\
\hline
\end{tabular}


ton abundance. The contribution of cladocera was just $4 \%$ (Table 2).

Rotifers were the most abundant species (in the class of eudominants and dominants): Keratella cochlearis f. cochlearis and Pompolyx sulcata, as well as Copepod's developmental stages (nauplii and copepodites) (Table 3 ).

Analysing the relationship between zooplankton abundance and physico-chemical parameters, a significant positive correlation was recorded at particular sites of the river with chlorophyll concentration $(r=0.75)$ and Norg. $(r=0.88)(p \leq 0.05)$. The average results of physicochemical analyses of waters from the Wel River were presented in Table 4.

\section{Spatial heterogeneity of zooplankton}

The sampling sites were divided into two groups: those that were right after the mouth of the lakes (sites: 1, 3a, and 4) and those away from the mouth of the lakes (sites: 2, 3, 5, and 6).

Most of the species, i.e. 46 and 56, were recorded at sites 1 and 4 . Both sites are located beyond the large flow-through lakes (Table 1). A considerable number of species was recorded also at site 3 (45 species). The site was located downstream of two tributaries: $\mathrm{Mu}-$ rawka Stream - a receiver of waters from fish ponds and the Koszelwska Stream, which drains the agricultural lands. The lowest number of 32 species was recorded at site 5 ( 32 species) (Table 1 ).
Rotifers had the highest contribution in the total number of species (64-88\%) at all sites. The largest number of species from this group were recorded at sites 3, 4 and 6 (Table 1).

There were clear differences in the species richness of crustaceans. The highest number of species, namely 12 Cladocera (including large genera, such as Leptodora, Diaphanosoma, and Daphnia) and 8 Copepoda were identified at site 4 . Site 1 was also rich in crustacean species with 2 species of Copepoda and 9 species of Cladocera. At the other sites crustacean plankton was very species-poor (Table 1).

The most abundant zooplankton community was recorded at site 4 (2300 ind. $\left.10 \mathrm{dm}^{-3}\right)$, ca. 1000 $\mathrm{m}$ beyond the lakes Tarczyńskie and Grądy (Fig. 1, Table 2). The contribution of individual groups was nearly identical with the averaged contribution for the whole river with rotifers dominating the zooplankton community. Cladocerans exhibited their highest abundance at this site with 110 ind. $10 \mathrm{dm}^{-3}$ (Table 2). Among Cladocera, the larger species dominated - Diaphanosoma brachyurum (Lievin, 1848) and Daphnia cucullata (G.O. Sars, 1862), as well as small species, such as Bosmina longirostris (O.F. Müller, 1785) and Chydorus sphaericus (O.F. Müller, 1776). Among copepods, nauplii and copepodites were dominant.

Nearly the same total abundance was recorded at site $3 \mathrm{a}$ ( 2258 ind. $10 \mathrm{dm}^{-3}$ ) with rotifers being the dominating group (50\%) (Table 2). Cladocerans ac-

Table 2. The abundance of zooplankton (ind. per $10 \mathrm{dm}^{3}$ ) and (\%) contribution of individual groups

\begin{tabular}{|c|c|c|c|c|c|c|c|c|c|c|c|c|c|c|c|c|}
\hline & \multicolumn{2}{|c|}{ Site 1} & \multicolumn{2}{|c|}{ Site 2} & \multicolumn{2}{|c|}{ Site 3a } & \multicolumn{2}{|c|}{ Site 3} & \multicolumn{2}{|c|}{ Site 4} & \multicolumn{2}{|c|}{ Site 5} & \multicolumn{2}{|c|}{ Site 6} & \multicolumn{2}{|c|}{ Mean } \\
\hline & $\mathrm{n}$ & $\%$ & $\mathrm{n}$ & $\%$ & $n$ & $\%$ & $\mathrm{n}$ & $\%$ & $\mathrm{n}$ & $\%$ & $\mathrm{n}$ & $\%$ & $\mathrm{n}$ & $\%$ & $\mathrm{n}$ & $\%$ \\
\hline ROTIFERA & 620 & 50 & 434 & 76 & 1136 & 50 & 228 & 65 & 1351 & 58 & 149 & 65 & 185 & 76 & 586 & 57 \\
\hline CLADOCERA & 59 & 5 & 10 & 2 & 43 & 2 & 26 & 7 & 110 & 6 & 4 & 2 & 14 & 6 & 38 & 4 \\
\hline COPEPODA & 554 & 45 & 126 & 22 & 1079 & 48 & 99 & 28 & 838 & 36 & 77 & 33 & 43 & 18 & 402 & 39 \\
\hline SUM & 1232 & 100 & 571 & 100 & 2258 & 100 & 353 & 100 & 2300 & 100 & 230 & 100 & 242 & 100 & 1026 & 100 \\
\hline
\end{tabular}

Table 4. The mean value results of physicochemical analyses of waters from the Wel River

\begin{tabular}{|c|c|c|c|c|c|c|c|c|}
\hline Site No. & $\mathrm{pH}$ & $\begin{array}{c}\text { EC } \\
\mu S \mathrm{~cm}-1\end{array}$ & $\begin{array}{c}\text { Ptot } \\
\mathrm{mg} \mathrm{dm}-3\end{array}$ & $\begin{array}{c}\mathrm{Nmin} \\
\mathrm{mg} \mathrm{dm}-3\end{array}$ & $\begin{array}{c}\text { Norg } \\
\text { mg dm-3 }\end{array}$ & $\begin{array}{c}\mathrm{PM} \\
\mathrm{mg} \mathrm{dm}-3\end{array}$ & $\begin{array}{c}\text { OM } \\
\%\end{array}$ & $\begin{array}{c}\text { Chl a } \\
\mu g d m-3\end{array}$ \\
\hline 1 & 8.3 & 307 & 0.063 & 0.24 & 1,40 & 3.12 & 67.9 & 12.01 \\
\hline 2 & 8.1 & 357 & 0.114 & 0.43 & 1,14 & - & - & - \\
\hline $3 a$ & 8.2 & 335 & 0.101 & 0.31 & 1,37 & 5.24 & 58.5 & 14.22 \\
\hline 3 & 8.2 & 339 & 0.090 & 0.58 & 1.03 & 5.38 & 52.3 & - \\
\hline 4 & 8.4 & 331 & 0.082 & 0.41 & 1,65 & 9.59 & 58.1 & 34.16 \\
\hline 5 & 8.1 & 367 & 0.104 & 0.75 & 1,17 & 4.86 & 48.5 & 6.82 \\
\hline 6 & 8.1 & 395 & 0.119 & 0.91 & 1.12 & 7.02 & 40.2 & 8.43 \\
\hline
\end{tabular}


Table. 3. The structure of zooplankton domination at particular sites based on the abundance

\begin{tabular}{|c|c|c|}
\hline Site No. & Class & Species \\
\hline \multirow[t]{2}{*}{1} & eudominants & $\begin{array}{c}\text { Keratella cochlearis } f \text {. cochlearis } \\
\text { nauplius } \\
\text { copepodites }\end{array}$ \\
\hline & dominants & Polyarthra dolichoptera \\
\hline \multirow[b]{2}{*}{2} & eudominants & Keratella cochlearis f. cochlearis \\
\hline & dominants & $\begin{array}{c}\text { Asplanchna priodonta } \\
\text { Polyarthra dolichoptera } \\
\text { nauplius }\end{array}$ \\
\hline \multirow[t]{2}{*}{$3 a$} & eudominants & $\begin{array}{c}\text { Keratella cochlearis f. cochlearis } \\
\text { Pompholyx sulcata } \\
\text { nauplius }\end{array}$ \\
\hline & dominants & $\begin{array}{l}\text { Polyarthra dolichoptera } \\
\text { copepodites }\end{array}$ \\
\hline \multirow[b]{2}{*}{3} & eudominants & $\begin{array}{c}\text { Anuraeopsis fissa } \\
\text { Keratella cochlearis f. cochlearis }\end{array}$ \\
\hline & dominants & $\begin{array}{c}\text { Keratella cochlearis f. tecta } \\
\text { Polyarthra dolichoptera } \\
\text { Chydorus sphaericus } \\
\text { nauplius }\end{array}$ \\
\hline \multirow[t]{2}{*}{4} & eudominants & $\begin{array}{c}\text { Keratella cochlearis f. cochlearis } \\
\text { nauplius } \\
\text { copepodites }\end{array}$ \\
\hline & dominants & $\begin{array}{l}\text { Keratella cochlearis f. tecta } \\
\text { Pompholyx sulcata }\end{array}$ \\
\hline \multirow{2}{*}{5} & eudominants & $\begin{array}{c}\text { Keratella cochlearis f. cochlearis } \\
\text { nauplius }\end{array}$ \\
\hline & dominants & $\begin{array}{l}\text { Keratella quadrata } \\
\text { copepodites }\end{array}$ \\
\hline \multirow[t]{2}{*}{6} & eudominants & $\begin{array}{c}\text { Brachionus angularis } \\
\text { Keratella cochlearis f. cochlearis } \\
\text { nauplius }\end{array}$ \\
\hline & dominants & $\begin{array}{c}\text { Keratella cochlearis f. tecta } \\
\text { Polyarthra dolichoptera }\end{array}$ \\
\hline \multirow{4}{*}{$\begin{array}{c}\text { All } \\
\text { samples }\end{array}$} & eudominants & $\begin{array}{c}\text { Keratella cochlearis f. cochlearis } \\
\text { nauplius }\end{array}$ \\
\hline & dominants & $\begin{array}{l}\text { Pompolyx sulcata } \\
\text { copepodites }\end{array}$ \\
\hline & subdominants & $\begin{array}{c}\text { Keratella cochlearis f. tecta } \\
\text { Keratella quadrata } \\
\text { Polyarthra dolichoptera }\end{array}$ \\
\hline & recedents & $\begin{array}{c}\text { Anuraeopsis fissa } \\
\text { Conochilus unicornis } \\
\text { Trichocerca pussila } \\
\text { Diaphanosoma brachyurum }\end{array}$ \\
\hline
\end{tabular}

counted for only $2 \%$ of the total number, although Daphnia cucullata and Diaphanosoma brachyurum were still the dominant species among cladocerans (Tables 2 and 3). Developmental stages were almost exclusively found among copepods (the average abundance of adults was only 5 ind. $10 \mathrm{dm}^{-3}$ ).
The zooplankton abundance at site 1 was lower (1232 ind. $10 \mathrm{dm}^{-3}$ ) compared with the other two sites that were also situated after a lake. At this site the dominance of Rotifera was quite evident - 50\%; copepods, which made up 45\%, were 2 -times less numerous compared with the other sites located just after lakes, and their abundance was mainly affected by developmental stages. Cladocerans had a 5\% contribution (Table 2 ) and were mainly represented by small species - Bosmina longirostris and Ceriodaphnia sp.

Generally the group of eudominants and dominants at these three sites comprises the following rotifers: Keratella cochlearis (Gosse, 1851) f. cochlearis and tecta, Pompholyx sulcata (Hudson, 1885) and Polyarthra dolichoptera (Idelson, 1925), as well as nauplii and copepodites of copepods (Table 3 ).

The other four sites, not situated directly beyond the lakes, were characterised by much lower abundance (Fig. 2).

Two of them (sites 2 and 3 ) are 8 and $11 \mathrm{~km}$ away from the lakes' outflows and are located just before the place where the river flows into the subsequent reservoir. The other two sites (sites 6 and 5) are located in the lower reaches of the watercourse along the river section of completely different nature compared with the sites described above (Table 2, Fig. 2 ). The fewest zooplankton individuals were recorded at site $5-230$ ind. $10 \mathrm{dm}^{-3}$.

According to the analysis of variance ANOVA with Tukey's post hock test for the abundance of zooplankton, it was found that sites $(1,3 \mathrm{a}$, and 4$)$ located just beyond the lakes differ statistically significantly from the sites in the free-flowing river (site 2) and the sites situated within the lower section of the river (sites 5 and 6). No statistically significant difference was found between sites 1 and 3; and 1 and 2. Also no statistically significant difference was recorded between sites $3 a$ and 3 ( Table 5).

Site 4 (with the highest count of zooplankton), and site $3 a$ differ statistically significantly from all the sites situated in the free-flowing river at a certain distance from lakes, i.e. from sites 2, 3, 5 and 6 (Fig. 2).

Cluster analysis (STATISTICA) revealed that sites $3 \mathrm{a}$ and 4 are the most similar to each other (located just outside the lakes), in the second group, the sites 5 and 6 are the most similar, located in the lower reaches of the river (free-flowing river), as well as site 3. Even though site 1 is also situated just beyond the river outflow from the lake, it is different from sites $3 \mathrm{a}$ and 4 (Fig. 3). 


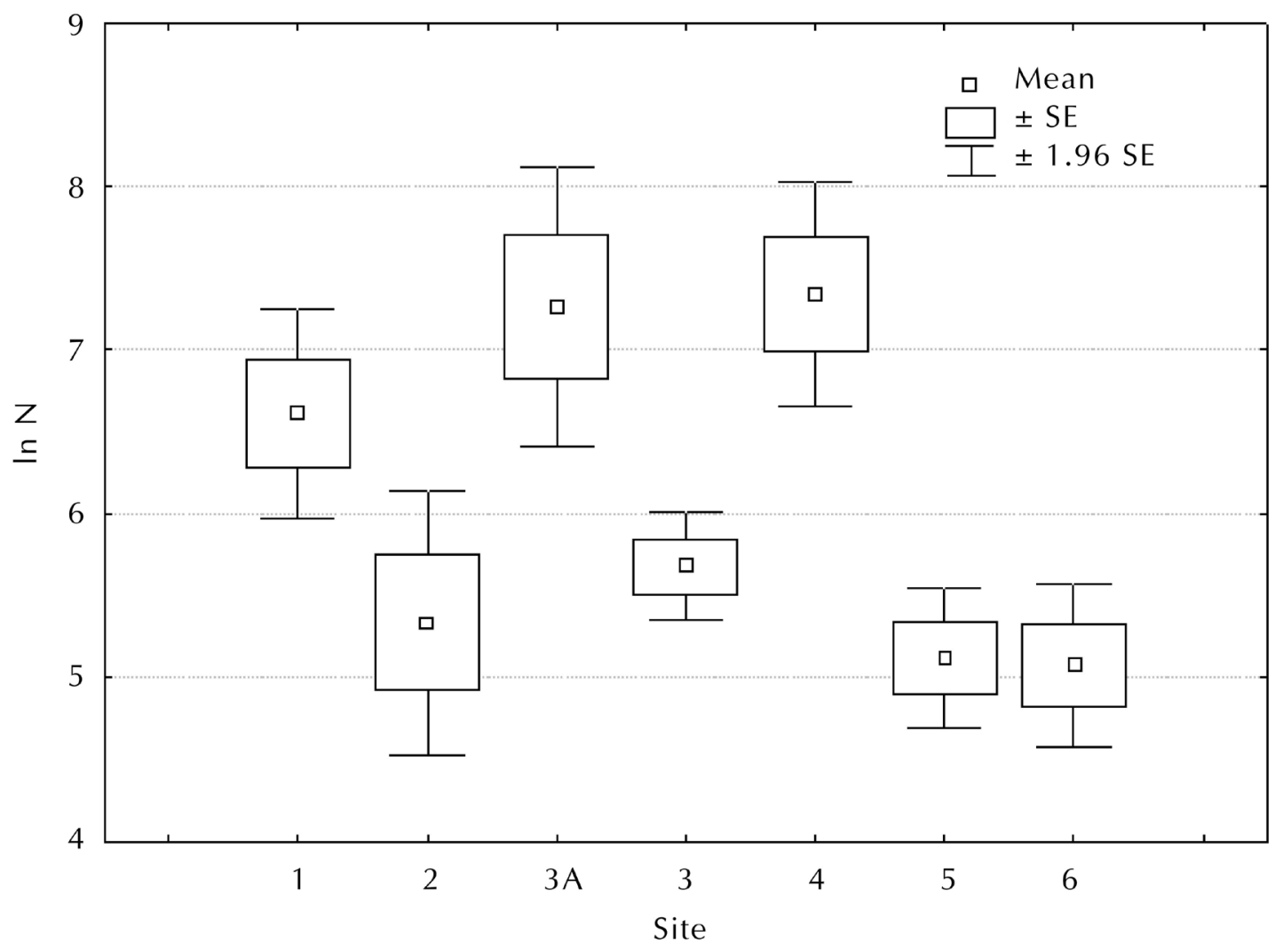

Fig. 2. The number of zooplankton expressed in $\ln \mathrm{N}$ at particular sites of the Wel River

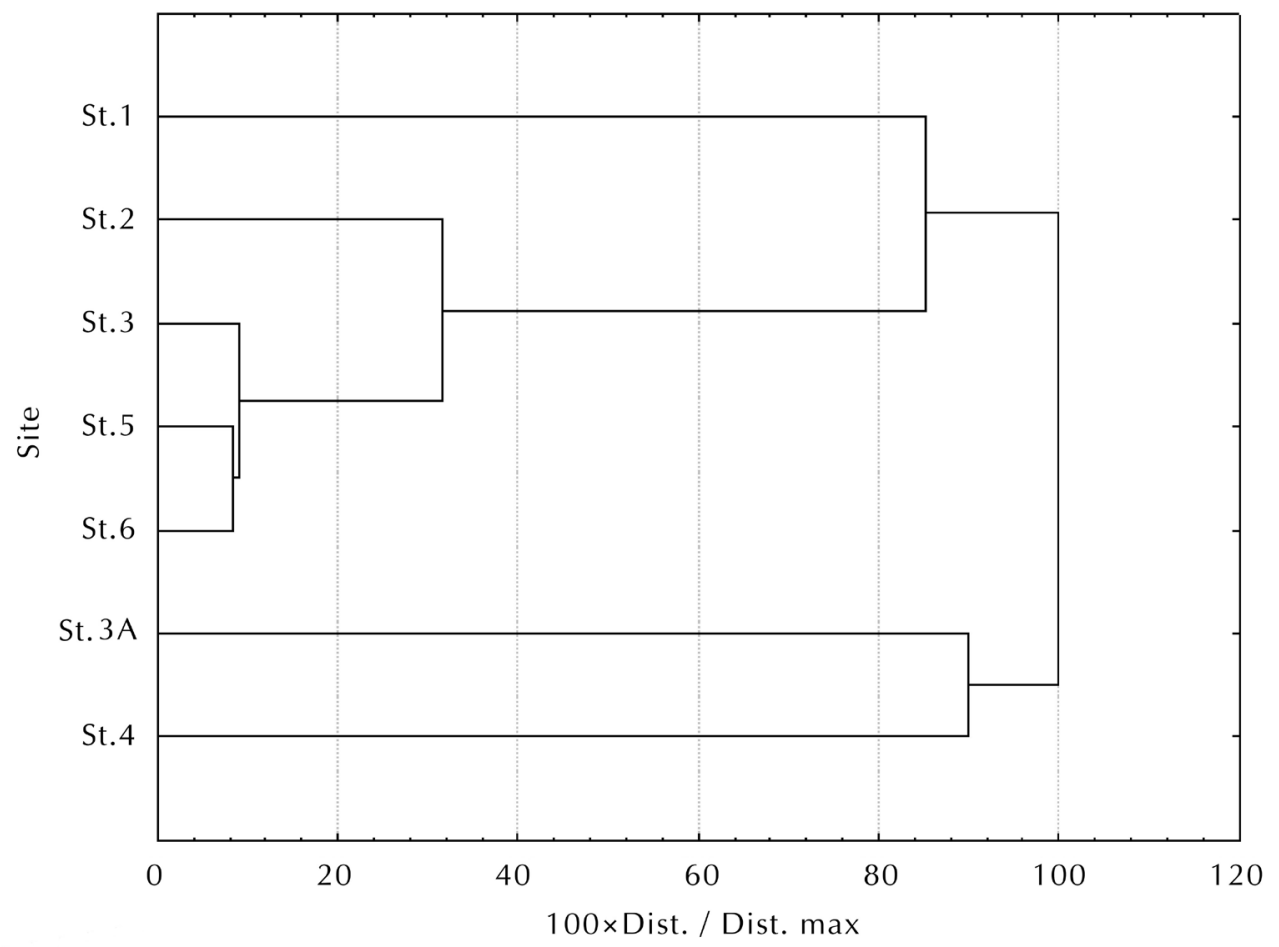

Fig. 3. Dendrogram. Single nodes. Euclidean distance between sites 
Table 5. Results of Tukey's HSD post hoc test. The marked differences are significant at $\mathrm{p}<0.05$

\begin{tabular}{cccccccc}
\hline Site No. & 1 & 2 & $3 a$ & 3 & 4 & 5 & $\mathbf{0}$ \\
\hline 1 & & 0.054969 & 0.94189 & 0.273669 & 0.613503 & $\mathbf{0 . 0 0 8 7 7 8}$ & $\mathbf{0 . 0 0 6 3 8 8}$ \\
\hline 2 & 0.054969 & & $\mathbf{0 . 0 4 3 7 2 8}$ & 0.983873 & $\mathbf{0 . 0 0 0 3 2 8}$ & 0.998742 & 0.996561 \\
\hline $3 a$ & 0.941890 & $\mathbf{0 . 0 4 3 7 2 8}$ & & $\mathbf{0 . 1 6 3 3 9 3}$ & 1.000000 & $\mathbf{0 . 0 1 6 5 3 1}$ & $\mathbf{0 . 0 1 3 5 7 5}$ \\
\hline 3 & 0.273669 & 0.983873 & $\mathbf{0 . 1 6 3 3 9 3}$ & & $\mathbf{0 . 0 0 3 8 1 1}$ & 0.819995 & 0.765608 \\
\hline 4 & 0.613503 & $\mathbf{0 . 0 0 0 3 2 8}$ & 1.000000 & $\mathbf{0 . 0 0 3 8 1 1}$ & & $\mathbf{0 . 0 0 0 1 4 8}$ & $\mathbf{0 . 0 0 0 1 3 9}$ \\
\hline 5 & $\mathbf{0 . 0 0 8 7 7 8}$ & 0.998742 & $\mathbf{0 . 0 1 6 5 3 1}$ & 0.819995 & $\mathbf{0 . 0 0 0 1 4 8}$ & 1.000000 \\
\hline 6 & $\mathbf{0 . 0 0 6 3 8 8}$ & 0.996561 & $\mathbf{0 . 0 1 3 5 7 5}$ & 0.765608 & $\mathbf{0 . 0 0 0 1 3 9}$ & 1.000000 \\
\hline
\end{tabular}

\section{Discussion}

\section{General composition of zooplankton}

The number of zooplankton taxa identified in the Wel River, is relatively high. The similar number of species was recorded in the Lower Vistula River and in the Vychegda River (Napiórkowski et al. 2006; Kononova 2009). Definitely fewer species were recorded in the Lower Odra River and in the Rhine River (Szlauer and Szlauer 1994; van Dijk and van Zanten 1995). Usually potamoplankton of large rivers is richer in comparison to small rivers (Basu and Pick 1996). It is not the case in the Wel River, where the lakes through which the river flows probably enriched the species composition.

Welker and Walz (1998), Burger et al. (2002) and Walks and Cyr (2004) emphasize that the fluvial zooplankton is usually a species poor community, when comparing its structure with species richness of lakes. However, Napiórkowski et al. (2006), reported that zooplankton in a big, lowland river Lower Vistula River can match or even exceed the species richness of a lake. The zooplankton species structure analysis in the Wel River proves that the plankton community of a small river flowing through a number of lakes can also be rich.

Rotifera dominated in the zooplankton species structure in the Wel River, as in all the aforementioned rivers (Table 1). Rotifera are better adapted to adverse conditions of lotic habitats than crustacean species (Marneffe et al. 1996; Demetraki-Paleolog 2004).

Among the crustaceans, both in the Wel River and in the compared rivers, most of the species belonged to Cladocera (9-21\%). These included both small cladocerans observed in many other rivers (Chydorus sphaericus, Bosmina longirostris) (Szlauer 1977; van Dijk and van Zanten 1995), as well as large species from the genera Daphnia, Ceriodaphnia, Diaphanosoma or Leptodora, whose presence resulted from the specific nature of the watercourse.

The abundance of zooplankton in the Wel River is low as compared with other rivers. The average density of zooplankton in the Lower Vistula River and the Lower Odra River was almost 4- and 5-times higher compared with the Wel River (Szlauer and Szlauer 1994; Napiórkowski et al. 2006). The most important factor eliminating plankton (reduction of abundance) in such a small river as the Wel River is a sudden change in hydrology - turbulent water motion and high flow velocity can physically injure organisms, as well as reduce the ability to catch the food (Viroux 1997).

In all compared rivers, also in the Wel River, Rotifera dominated quantitatively (57\%); and among crustaceans - Copepoda, probably due to a high contribution of developmental stages, resistant to hydraulic stress (Ejsmont-Karabin and Węgleńska 1996; Havel and Shurin 2004).

In general, the plankton of the Wel River was characterised by a relatively high contribution of Crustacea (Cladocera and Copepoda) in the total abundance (Table 2) as in the Płonia River (Czerniawski 2008). Both watercourses are small rivers, which cut through several open lakes. The specificity of zooplankton in this type of watercourses is significantly different from the nature of this grouping in typical large rivers (Basu and Pick 1996; Viroux 1999). The production of zooplankton in the main stream of small rivers, if any, is of minor importance (Vadadi-Fülöp 2009), and its existence is supported by a continuous inflow of specimens from lentic sources (quiet bays, oxbow lakes, broads, dams, and also lakes) (Demetraki-Paleolog 2007). 
Spatial heterogeneity of zooplankton

A river flowing through many lakes may play an important role in the distribution of species (Shurin and Havel 2003). The stream corridor is one of the routes for dispersal of zooplankton (Havel and Shurin 2004).

The sites 1, 3a and 4, located directly beyond the lakes were generally characterised by higher taxonomic richness of Crustacea, compared with the sites situated in typically fluvial sections of the watercourse ( sites: 2, 3, 5, and 6) (Table 1). Similar conclusions were reached by Czerniawski and Domagała (2012).

A distance to the river outflow from the lake affects the qualitative composition of zooplankton in the watercourse (Czerniawski 2008). Changes in the species structure of zooplankton over a river section of several kilometres long can be analysed by comparing sites 1 and 2, as well as sites $3 \mathrm{a}$ and 3 . Over the distance of 11 $\mathrm{km}$, between sites 1 and 2, 11 rotifer species were eliminated from the community (mainly typical lacustrine forms). However 10 new species turned up, including 7 tychoplankton species. Six species of cladocerans were eliminated from the community of crustaceans. Among Copepoda, adult forms were completely eliminated.

Similarly between the sites $3 \mathrm{a}$ and 3 , over the distance of $8 \mathrm{~km}$, the number of rotifer species decreased by 9 (mainly plankton species), and they were replaced by 10 tychoplankton species. Among cladocerans, large species were completely eliminated from the community. At both sites, located a few kilometres away from the lake, larval stages of Copepoda were observed. Similar structural changes in zooplankton were observed by Szlauer (1977), Sandlund (1982), Ejsmont-Karabin and Węgleńska (1996), Czerniawski and Domagała (2012). The sharp spatial changes of zooplankton structure in the river reflected the influence of lakes on the river continuum.

Site 5 and site 6 are located in the lower reach of the watercourse, where many species are eliminated under influence of hydrological stress (Table 1). According to some authors (Ejsmont-Karabin and Węgleńska 1996; Czerniawski 2008; Chang et al. 2008), a small number of species is typical of lower sections of small rivers.

Based on the taxonomy and richness of zooplankton, the sites can be divided into two groups: sites located several hundred metres beyond the flowthrough lakes (site 1 , site $3 a$, site 4 ), and typically fluvial sites (site 2, site 3, site 5, site 6) (Table 2 and Fig. 2 ). These two groups of locations differ significantly, which is reflected in the results of Tukey's test (Fig. 2).
The representation of zooplankton at the outflow from a reservoir is usually proportional to the abundance of plankton in a lake (Ejsmont-Karabin and Węgleńska 1996; Czerniawski and Domagała 2012).

At sites 2 and 3 there are changes in the plankton carried out from the lakes after it flows through a typical fluvial section of several kilometres long. The abundance of zooplankton decreased 2 and 6 times, respectively at sites 2 and 3, compared with the preceding sites situated at the outflow from the lakes (site 1 and site 3a). The contribution of Rotifera in the total abundance of zooplankton increased - in the former case from $50 \%$ to $76 \%$, and in the latter - from $50 \%$ to $65 \%$ (Table 2).

The same relationship was recorded by Szlauer (1977), Sandlund (1982), Ejsmont-Karabin and Węgleńska (1996), Welker and Walz (1999), Walks and Cyr (2004), Czerniawski and Domagała (2010).

According to some authors (Sandlund 1982; Walks and Cyr 2004), a quick reduction in the abundance of zooplankton flowing from the lakes should be attributed mainly (and even exclusively) to preying fry and benthic filtrators. Others (Ejsmont-Karabin and Węgleńska 1996; Viroux 1997), apart from the pressure of predators as a significant factor eliminating the lake plankton, quote a sudden change in hydrology - a short retention time reduces the ability to reproduce, turbulent water motion and high flow velocity can physically injure the organisms, as well as reduce their ability to catch the food. Some authors emphasize the importance of the increased concentration of suspended mineral matter, which negatively affects the fertility and efficiency of filtration (Ejsmont-Karabin and Węgleńska 1996; Welker and Walz 1998). Probably all these factors had an impact on the studied zooplankton of the River. However the hydrological conditions could be crucial in the case of the Wel River.

Sites 5 and 6 located in the lower reaches of the river were characterised by the lowest average count of zooplankton and high contribution of Rotifera in the abundance (Fig. 2); a similar trend was also observed in the Płonia River (Czerniawski 2008). The structure of zooplankton at these sites resembled mostly a typical, fluvial plankton community (Table 2 ).

Rotifer species dominated in quantitative terms as well as nauplii and copepodites Copepoda (in the class of eudominants and dominants at particular sites (Table 3). These dominants are typical of rivers like the Vistula River (Napiórkowskiet et al. 2006), Rhine 
(van Dijk and van Zanten 1995) and Mozela (Viroux 1993).

The ratio of pelagic to bentholittoral species in the Wel River is the same as in the Vistula River (including Włocławek Dam Reservoir) 56\% : 44\% (Kentzer et al. 2010). A completely different situation was observed in a small river - the Drwęca (part without lakes) 30\% : $70 \%$ (unpubl. data) and in the lower Vistula River 66\% : 34\% (Napiórkowski and Napiórkowska 2013).

The above data indicate that a small river flowing through the lakes is similar to a large river flowing through the dam reservoir in terms of the nature of the species composition.

In natural rivers, which do not flow through reservoirs, the size of the river determines the ratio of pelagic to bentholittoral species (Ejsmont-Karabin and Kruk 1998; Żurek 2000). Large rivers create better possibilities for the development of potamozooplankton: slower flow, better food condition and more ecological niches (van Dijk and van Zanten 1995; Marneffe et al. 1996).

Based on the analysis of physicochemical data, we can see that the lakes through which the Wel River flows are moderately eutrophic. The lakes can be a source of biogenic substances and organic matter for the river (Hillbricht-Ilkowska 1999) (Table 4). Organic matter can be carried away i.a. in the form of phytoplankton, which is reflected by the concentration of chlorophyll $a$ ( Dembowska et al. 2009). A significant positive correlation (Pearson's) was recorded at particular sites of the river between the total number of zooplankton and chlorophyll $a(0.75)$ and $\mathrm{N}_{\text {org. }}$ (0.88) $(\mathrm{p} \leq 0.05)$.

Based on the cluster analysis (Fig. 3), one can clearly see that sites $3 \mathrm{a}$ and 4 (located just beyond the lakes) are very similar to each other; sites 5 and 6 situated at the lower section of the river are at the other extreme, and site 3 in the free-flowing river in the middle reaches of the river. It seems that both in the physico-chemical terms and in respect of zooplankton biodiversity, the sites create two groups. It is interesting that site 1 , also situated beyond the lake, differs from sites $3 \mathrm{a}$ and 4 . Probably this reservoir is of slightly different nature, which can be reflected in some physicochemical parameters, e.g. EC, TP, $\mathrm{N}_{\text {min }}$ and PM have the lowest values among all the studied sites (Table 4). At the same time, the concentration of chlorophyll $a$ is lower compared with similar sites $3 \mathrm{a}$ and 4 . The river at this site and the preceding lake require further researches.

\section{Conclusions}

Many authors (Allan 1998; Lampert and Sommer 2007; Chang et al. 2008) believe that zooplankton in small rivers cannot develop in the main stream, and its presence in the watercourse is determined and supported by a continuous inflow of individuals from external springs.

Natural flow-through reservoirs on rivers of a low Strahler number cause some kind of transposition of conditions and properties characteristic of rivers with a higher Strahler number into a "younger" fluvial system (Hillbricht-Ilkowska 1999). In such conditions, a community of zooplankton may appear in a small river with a low Strahler number, as confirmed by the research performed in the Wel River.

Based on the analysis of species structure and density of the zooplankton community, the following can be concluded:

- flow-through lakes could disturb the river continuum, but their impact on changes in the qualitative and quantitative structure of zooplankton is shortlived,

- probably lakes are the main source of zooplankton in the river-lake system of the Wel River,

- due to the presence of flow-through lakes along the river, species richness of zooplankton in the Wel River is similar to large rivers,

- the Wel River is characterised by very variable hydrological conditions, and thus a high diversity of habitats along its course, and this is reflected in considerable differences in the structure of zooplankton communities along different sections of the watercourse.

\section{References}

Allan J.D., 1998, Ekologia wód płynących (The stream ecology. Structure and function of running waters), PWN, Warszawa, p. 452 (Polish edition).

Basu K.B., Pick, F.R., 1996, Factors regulating phytoplankton and zooplankton biomass in temperate rivers, Limnol. Oceanogr. 41(7): 1572-1577.

Burger D.F., Hogg I.D., Green J.D., 2002, Distribution and abundance of zooplankton in the Waikato River, New Zeeland, Hydrobiologia 479: 31-38.

Chang K.H., Doi H., Imai H., Gunji F., Nakano I., 2008, Longitudial changes in zooplankton distribution below a reservoir outfall with reference to river planktivory, Limnology 9: 125-133.

Clarke K.R., 1993, Non-parametric multivariate analysis of changes in community structure, Austral. J. Ecol. 18: 117-143. 
Czarnecka H. (ed.), 2005, Atlas podziatu hydrograficznego Polski. Cz. 1: Mapy w skali 1:200000, Cz. 2: Zestawienie zlewni (Atlas of the hydrographic division of Poland. Part 1: Maps in 1:200000 scale, Part 2: Tabulation of river basins), Wyd. IMGW, Warszawa, p. 562.

Czerniawski R., 2008, The effect of flow-through reservoirs on zooplankton of the Płonia river, Pol. J. Nat. Sc. 23(3): 583-597.

Czerniawski R., Domagała J., 2010, Similarities in zooplankton community between River Drawa and its two tributaries (Polish part of River Odra), Hydrobiologia 638: 137-149.

Czerniawski R., Domagała J., 2012, Potamozooplankton communities in three different outlets from mesotrophic lakes located in lake-river system, Oceanol. Hydrobiol. Stud. 41: 46-56.

Dembowska E., Głogowska B., Krokwińska A., 2009, Dynamics of algae communities in pond and stream in Toruń, Limnol. Papers 4(1): 41-53.

Demetraki-Paleolog A., 2004, Planktonic rotifers diversity in selected rivers of the Vistula, Wieprz and San drainage-basins, Teka Kom. Ochr. Kszt. Środ. Przyrod. 1: 44-50.

Demetraki-Paleolog A., 2007, Wrotki (Rotifera) planktonowe rzek zachodniej Lubelszczyzny (Planktonic rotifers (Rotifera) in rivers of western Lublin Region), Rozpr. Nauk. 317, Wyd. AR Lubl., Lublin, p. 122 (in Polish).

Edmondson W.T., Winberg G.G., 1971, A manual on the methods for the assessment of secondary productivity in fresh waters, IBP Handbook No. 17, Blackwell Sci. Publ., Oxford, p. 358.

Ejsmont-Karabin J., Węgleńska T., 1996, Przemiany struktury zooplanktonu w strefach przejściowych rzeka-jeziororzeka: System rzeki Krutyni, Pojezierze Mazurskie (Transformation of the zooplankton structure in the transitional zones of river-lake-river: System of the Krutynia River, Masurian Lakeland), [in:] The functioning of river-lake systems in lakeland landscape: Krutynia River (Masurian Lakeland, Poland Zesz. Nauk. Kom. Nauk "Człowiek i Środowisko" PAN 13: 263-289 (in Polish, English summary).

Ejsmont-Karabin J., Kruk M., 1998, Effect of contrasting land use on free-swimming rotifer communities of streams in Masurien Lake District, Poland, Hydrobiologia 387/388: 241-249.

Golterman H.J., 1971, Methods for chemical analysis of fresh waters, IBP Handbook No. 8, Blackwell Sci. Publ., Oxford, p. 165.

Greenberg A.E., Clesceri L.S., Eaton A.D. (eds), 1992, Standard methods for the examination of water and wastewater, APHA-AWWA-WEF, Washington.

Harris R.P., Wiebe P.H., Lenz J., Skjoldal H.R., Huntley M. (eds), 2000, Zooplankton methodology manual, ICES Academic Press, London, p. 684.

Havel J.E., Shurin J.B., 2004, Mechanisms, effects and scales of dispersal in freshwater zooplankton, Limnol. Oceanogr. 49(4 part 2): 1229-1238.

Hill T., Lewicki P., 2005, Statistics: methods and applications, StatSoft Inc., Tulsa, p. 800.
Hillbricht-Ilkowska A., 1999, Shallow lakes in lowland river systems: Role in transport and transformations of nutrients and in biological diversity, Hydrobiologia 408/409: 349-358.

Kasprzak K., Niedbała W., 1981, Wskaźniki biocenotyczne stosowane przy porządkowaniu i analizie danych w badaniach ilościowych (Biocenotic indicators used for ordering and analyzing data in quantitive research), [in:] Górny M., Grüm L. (eds), Metody stosowane w zoologii gleby (Methods used in soil zoology), PWN, Warszawa: 397-408 (in Polish).

Kentzer A., Dembowska E., Giziński A., Napiórkowski P., 2010, Influence of the Włocławek Reservoir on hydrochemistry and plankton of a large, lowland river (the Lower Vistula River, Poland), Ecol. Eng. 36(12): 17471753.

Kobayashi T., 1997, Associations between environmental variables and zooplankton body masses in regulated Australian river, Mar. Freshwater Res. 48(6): 523-529.

Kononova O.N., 2009, Zooplankton in the Vychegda River, Inl. Wat. Biol. 2(2): 149-156.

Lampert W., Sommer U., 2007, Limnoecology: The Ecology of Lakes and Streams, Oxford University Press, Oxford, p. 324.

Marneffe Y., Descy J.P., Thome J.P., 1996, The zooplankton of the lower river Meuse, Belgium: seasonal changes and impact of industrial and municipal discharges, Hydrobiologia 319: 1-13.

McCauley E., 1984, The estimation of abundance and biomass of zooplankton in samples, [in:] Downing J.A., Rigler F.H. (eds), A manual on methods for assessment of secondary productivity in fresh waters, IBP Handbook No. 17, Blackwell Sci. Publ. Oxford: 228-261.

Mieszczankin T., 2000, Total and non-living suspended matter of the lower Vistula River. Part V, Limnol. Papers 21: 44-50.

Mieszczankin T., 2009, The influence of the saline, industrial contaminants on the water quality of the Vistula River near the city of Toruń, Limnol. Papers 4(1): 25-32.

Napiórkowski P., Kentzer A., Dembowska E., 2006, Zooplankton of the lower Vistula River: the effect of Włocławek Dam Reservoir (Poland) on community structure, Verh. Int. Ver. Limnol. 29: 2109-2114.

Napiórkowski P., Napiórkowska T., 2013, The diversity and longitudinal changes of zooplankton in the lower course of large, regulated European river (the lower Vistula River, Poland), Biologia 68(6): 1163-1171.

Nogrady T., Wallace R.L., Snell T., 1993, Rotifera 1. Biology, Ecology and Systematics, [in:] Dumont H.J.F. (ed.), Guides to the Identification of the Microinvertebrates of the Continental Waters of the World Pt. 4, SPB Acad. Publ. BV., The Hague, p. 142.

Operacz M., Kentzer A., Nowaczyk Ł., 2011, The content of nitrogen compounds in the Wel River in the light of the Nitrates Directive, Ecological Questions 15: 23-29.

Pourriot R., Rougier C., Miquelis A., 1997, Origin and development of river zooplankton: example of the Marne, Hydrobiologia 345: 143-148. 
Sandlund O.T., 1982, The drift of zooplankton and microzoobenthos in the river Strandaelva, western Norway, Hydrobiologia 94: 33-48.

Shurin J.B. and Havel J.E., 2003, Hydrologic connections as dispersal routs for the spread of exotic cladoceran Daphnia lumholtzi, Biol. Invasions 4: 431-439.

Szlauer B., 1977, The zooplankton removal from lakes by the river Płonia, Acta Ichth. Piscat. 7(1): 59-76.

Szlauer B., Szlauer L., 1994, Zooplankton rzeki Odry w Szczecinie (The zooplankton of Oder River in Szczecin), Zesz. Nauk. AR Szczec. 164: 23-39 (in Polish).

Thorp J.H., Caspar A.F., 2003, Importance of biotic interactions in large rivers: An experiment with planktivorous fish, dreissenid mussels and zooplankton in the St. Lawrence River, River Res. Applic. 19: 265-279.

Vadadi-Fülöp Cs., 2009, Zooplankton (Cladocera, Copepoda) dynamics in the River Danube upstream and downstream of Budapest, Hungary, Opusc. Zool. 40(2): 87-98.

van Dijk G.M., van Zanten B., 1995, Seasonal changes in zooplankton abundance in the lower Rhine during 1987-1991, Hydrobiologia 304: 29-38.

Vannotte R.L., Minshall G.W., Cummins K.W., Sedell J.R., Cushing C.E., 1980, The river continuum concept, Can. J. Fish. Aquat. Sci. 37: 130-137.

Viroux L., 1997, Zooplankton development in two large lowland rivers, the Moselle (France) and the Meuse (Belgium), in 1993, J. Plankton Res. 19(11): 1743-1762.
Viroux L., 1999, Zooplankton distribution in flowing waters and its implication for sampling: case studies in the River Meuse (Belgium) and the River Moselle (France, Luxembourg), J. Plankton Res. 21(7): 1231-1248.

Walks D.J., Cyr H., 2004, Movement of plankton through lake-stream systems, Freshwater Biol. 49: 745-759.

Ward J.V., Stanford J.A., 1995, The serial discontinuity concept: extending the model to floodplain rivers, Reg. Riv. Res. Manage. 10: 159-168.

Welker M., Walz N., 1998, Can mussels control the plankton in rivers?- a planktonological approach applying a Lagrangian sampling strategy, Limnol. Oceanogr. 43(5): 153-162.

Welker M., Walz N., 1999, Plankton dynamics in a river-lake system - on continuity and discontinuity, Hydrobiologia 408/409: 233-239.

Zimmermann-Timm H., Holst H., Kausch H., 2007, Spatial dynamics of rotifers in a large lowland river, the Elbe, Germany: How important are retentive shoreline habitats for plankton community?, Hydrobiologia 593: 4958.

Żurek R., 2000, Diversity of flora and fauna in running waters of the Province of Cracov (Southern Poland) in relation to water quality. 4. Zooseston, Acta Hydrobiol. 42(3/4): 331-345. 